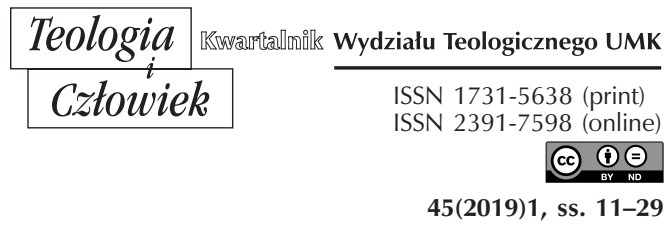

KS. DARIUSZ KWIATKOWSKI

WYDZIAŁ TEOLOGICZNY UNIWERSYTETU IM. ADAMA MICKIEWICZA W POZNANIU KWIATKOWSKI@POST.PL ORCID: 0000-0002-8014-0016

\title{
EUCHARYSTIA DAREM DLA KOŚCIOŁA I DLA ŚWIATA W ŚWIETLE ADHORTACJI APOSTOLSKIEJ BENEDYKTA XVI SACRAMENTUM CARITATIS
}

DOI: http://dx.doi.org/10.12775/TiCz.2019.001

Streszczenie. Artykuł ukazuje Eucharystię jako dar dany przez Chrystusa Kościołowi i światu. Źródłem refleksji jest adhortacja apostolska Sacramentum Caritatis Ojca Świętego Benedykta XVI. Chrystus ustanowił Eucharystię, aby na zawsze pozostać obecnym w swoim Kościele. Eucharystia celebrowana przez Kościół uobecnia pod osłoną sakramentalnych znaków śmierć i zmartwychwstanie Jezusa. Dzięki temu miłość Chrystusa udziela się nieustannie całemu Kościołowi. Eucharystia buduje Kościół i nieustannie go ożywia. Uczestniczący w Eucharystii są powołani, aby mocą miłości Chrystusa przemieniać oblicze świata i budować cywilizację miłości.

Słowa kluczowe: Eucharystia; uobecnienie; Kościół; życie wieczne.

Abstract. The Eucharist as a Gift for the Church and World in the Light of the Apostolic Exhortation Sacramentum Caritatis of the Holy Father Benedict XVI. This article reveals the Eucharist as a gift given by Christ for the Church and world. The source of reflection is the Apostolic Exhortation Sacramentum Caritatis of the Holy Father Benedict XVI. Christ instituted the Eucharist to be present in his Church forever. The Eucharist which is celebrated through the Church makes present under the sacramental 
species, the Death and Resurrection of Jesus. Thanks to this, the whole Church is granted the love of Christ. The Eucharist builds and revives the Church constantly. All who take part in the Eucharist are called through the power of Christ's love to transform the face of this world and build the civilisation of love.

Key words: Eucharist; Re-presentation (made present); Church; Eternal life.

Sobór Watykański II nazwał Eucharystię źródtem i zarazem szczytem całego życia chrześcijańskiego ${ }^{1}$. W Eucharystii zawiera się całe dobro duchowe Kościoła, czyli Jezus Chrystus, będący naszą Paschą i Chlebem żywym, który przez swoje ożywione przez Ducha Świętego i ożywiające Ciało daje życie ludziom². Swoją zbawczą skuteczność czerpie ona z realnej obecności Chrystusa. Konstytucja o liturgii Sacrosanctum Concilium przypomniała również, że dla urzeczywistniania wielkiego dzieła zbawienia Chrystus jest zawsze obecny w swoim Kościele, a szczególnie w czynnościach liturgicznych. Przede wszystkim jest On obecny w ofierze Mszy Świętej w osobie celebrującego kapłana oraz pod postaciami eucharystycznymi. Podkreśla się także obecność w głoszonym słowie Bożym oraz w zgromadzonym ludzie modlącym się i śpiewającym psalmy ${ }^{3}$. Posoborowe nauczanie Kościoła o Eucharystii bardzo mocno zwracało uwagę na realną i rzeczywistą obecność Chrystusa, a także na uobecniające się podczas każdej Mszy świętej dzieło zbawienia. Uczestnicząc w Eucharystii człowiek w sposób szczególny włącza się w toczącą się nieustannie historię zbawienia.

Myśli te podejmuje i rozwija Ojciec Święty Benedykt XVI w posynodalnej adhortacji Sacramentum Caritatis. Papież stwierdza: „Celebracja eucharystyczna pojęta jako źródło i szczyt egzystencji Kościoła, jawi się jako darmowa moc dająca życie światu i Kościołowi”" Św. Paweł w Pierw-

${ }^{1}$ Konstytucja dogmatyczna o Kościele Lumen Gentium, nr 11, w: Sobór Watykański II, Konstytucje. Dekrety. Deklaracje, tekst polski, nowe tłumaczenie, Poznań 2002, s. 113 (dalej: KK) .

2 Por. Dekret o posłudze i życiu prezbiterów Presbyterorum ordinis, nr 5, w: Sobór Watykański II, Konstytucje. Dekrety. Deklaracje, s. 483-484 (dalej: DP) .

${ }^{3}$ Zob. Konstytucja o Liturgii Świętej Sacrosanctum Concilium, nr 7, w: Sobór Watykański II, Konstytucje. Dekrety. Deklaracje, s. 51 (dalej: KL).

${ }^{4}$ Benedykt XVI, Posynodalna Adhortacja Apostolska Sacramentum Caritatis, Poznań 2007, nr 70 (dalej: ASC). 
szym Liście do Koryntian przypomina chrześcijanom: „Ponieważ jeden jest chleb, przeto my, liczni, tworzymy jedno ciało" $(10,17)$. Te słowa Apostoła stały się punktem wyjścia dla kardynała Josepha Ratzingera do ukazania relacji: Eucharystia - Kościól ${ }^{5}$. W tym kontekście należy rozumieć, że „ciałem” jest Kościół, a „chlebem” Jezus Chrystus. Stąd kardynał Ratzinger pisze: „Eucharystia jest tu więc rozumiana w kategoriach dynamiczno-eklezjologicznych, jako żywy akt, przez który dokonuje się ciągły rozwój Kościoła”' Tę myśl rozwija potem jako papież w pierwszej adhortacji poświęconej w całości Najświętszej Eucharystii, pisząc: „nowość Eucharystii polega na ciągłej przemianie życia chrześcijan, pokazując związek pomiędzy rzeczywistością eucharystyczną a chrześcijańską egzystencją w codzienności" ${ }^{\prime}$. Celem artykułu jest ukazanie sakramentu Eucharystii jako źródła dającego ciągłe istnienie oraz rozwój Kościoła i świata. Benedykt XVI mocno podkreśla, że Eucharystia stanowi rzeczywistość przekraczająca granice ziemskiego czasu. Dlatego w ostatnim punkcie przedstawimy Eucharystię jako źródło życia wiecznego.

\section{EUCHARYSTIA TWORZY, JEDNOCZY I DAJE ŻYCIE KOŚCIOŁOWl}

Soborowa konstytucja liturgiczna Sacrosanctum concilium podkreśla, że sakrament Eucharystii jest szczytem, do którego zmierza działalność Kościoła i zarazem źródłem, z którego wypływa cała jego moc ${ }^{8}$. Dzieje się tak, ponieważ każda Eucharystia uobecnia tajemnicę śmierci i zmartwychwstania Jezusa Chrystusa. Kościól, celebrując Eucharystię, nieustannie uobecnia i uczestniczy w tych najważniejszych zbawczych wydarzeniach, które dokonały się w historii świata. Papież Benedykt XVI stwierdza jasno i konkretnie: „Przez sakrament Eucharystii Jezus włącza wiernych w swoją własną "godzinę»; w ten sposób ukazuje więź, jaką pragnął nawiązać pomiędzy sobą a nami, pomiędzy sobą a Kościołem"9. Nawiązanie relacji

\footnotetext{
${ }^{5}$ Por. J. Ratzinger, Eucharystia - Bóg blisko nas, Kraków 2005, s. 131-132.

6 Tamże, s. 132.

7 Por. ASC, nr 72.

${ }^{8}$ Por. KL, nr 10.

9 ASC, nr 14; por. J. Aldazábal, L’Ecucaristia, w: La celebrazione nella Chiesa.
} I sacramenti, red. D. Borobio, t. 2, Torino1994, s. 383-391. 
między Chrystusem i Kościołem oraz Chrystusem i wiernymi dokonało się w momencie śmierci Chrystusa na krzyżu. Tu i teraz to zbawcze wydarzenie uobecnia się w każdej Mszy Świętej. W ofierze krzyża Chrystus zrodził Kościół jednocześnie jako swoją Oblubienicę i swoje Ciało.

Życie i obecność Jezusa Chrystusa są warunkami liturgicznego działania, które dokonuje się za sprawą obecności Ducha Świętego, koniecznego do istnienia Kościoła. Dla istnienia i życia Kościoła na ziemi konieczne jest działanie i obecność Ducha Świętego, który stanowi źródło miłości rozlanej przez Jezusa Chrystusa w sakramencie Eucharystii ${ }^{10}$. Ojciec Święty Jan Paweł II w encyklice Ecclesia de Eucharystia naucza: „W Eucharystii ma miejsce to wspólne i nierozłączne działanie Syna i Ducha Świętego, które było u początków Kościoła, powoływało go do życia i stanowiło o jego trwaniu"11. To niezwykłe działanie osób boskich w Eucharystii Benedykt XVI nazywa miłością trynitarną, która kieruje całą historią zbawienia. W pokarmie eucharystycznym całe Boże życie dociera do człowieka i udziela się w formie sakramentu. Papież stwierdza, że „Jezus Chrystus, który „przez Ducha wiecznego złożył Bogu samego siebie jako nieskalaną ofiarę" (Hbr 9, 14), w darze eucharystycznym udziela nam tego samego Bożego życia" ${ }^{12}$. Należy widzieć tutaj absolutnie bezinteresowny dar, który Kościół przyjmuje, celebruje i adoruje w wiernym posłuszeństwie.

Jan Paweł II w encyklice Ecclesia de Eucharistia, mówiąc o ustanowieniu Eucharystii, zwraca uwagę, że: „Od tej chwili aż do końca czasów, Kościół buduje się przez tę Komunię sakramentalną z Synem Bożym, który się za nas wydał: „To czyńcie na moją pamiątkę... Czyńcie to, ile razy pić będziecie, na moją pamiątkę" (1 Kor 11, 24-25; por. Łk 22, 19)"13. Włączenie wiernych w sakramentalną Komunię staje się głównym źródłem żywotności Kościoła. Ostatnia Wieczerza rozwija w sercach wierzących miłość objawiająca się w każdym ludzkim działaniu. Uobecnienie zbawczych czynów Jezusa Chrystusa dokonuje się zawsze

10 Por. B. Nadolski, Wprowadzenie do liturgii, Kraków 2004, s. 70.

${ }^{11}$ Jan Paweł II, Encyklika o Eucharystii w życiu Kościoła Ecclesia de Eucharistia, Poznań 2003, nr 23 (dalej: EE).

12 Por. ASC, nr 8.

${ }^{13}$ EE, nr 21; por. J. Nagórny, Eucharystia - we wspólnocie i dla wspólnoty, w: Eucharystia - miłość i dziękczynienie, red. W. Słomka, A.J. Nowak, Lublin 1992, s. 123-140. 
tam, gdzie sprawowana jest Msza Święta. Źródłem życia Kościoła staje się aktualizacja męki i śmierci Jezusa. Chrystus nadaje treść eklezjalnemu doświadczeniu czasu ${ }^{14}$.

Ojciec Święty Benedykt XVI w adhortacji Sacramentum Caritstis stwierdza, iż: „Wewnętrzne piękno liturgii ma jako swój właściwy podmiot Chrystusa zmartwychwstałego i uwielbionego w Duchu Świętym, w którym mieści się Kościół wraz ze swym działaniem”15. Tym działaniem Kościoła jest przede wszystkim Eucharystia, która stanowi, że Kościół żyje i rozwija się w każdym czasie ${ }^{16}$. W sprawowaniu Eucharystii zawsze realizuje się Boski zamysł Ostatniej Wieczerzy i słów Jezusa Chrystusa, które wypowiedział w Wieczerniku do Apostołów: „To czyńcie na moja pamiątkę" (1 Kor 11, 24-25; Łk 22, 19). Słowa wypowiedziane przez Jezusa Chrystusa nie tracą na wartości w miarę upływu lat, a wręcz przeciwnie, wypowiadane przez usta kapłanów sprawiają, że Kościół żyje i rozwija się wszędzie tam, gdzie znajdzie się osoba kapłana. Kościół, czyli królestwo Chrystusa, już teraz obecne w misterium, z mocy Boga rośnie w sposób widzialny w świecie ${ }^{17}$.

Benedykt XVI ukazuje ogromną rolę Eucharystii w życiu i działalności Kościoła. Pisząc o celu napisania adhortacji Sacramentum Caritatis, papież wyraża swoje pragnienie w takich słowach: „pragnę w obecnym dokumencie polecić nade wszystko, by lud chrześcijański pogłębił więź istniejącą pomiędzy tajemnicą eucharystyczną, akcją liturgiczną oraz nową służbą duchową wynikającą z Eucharystii jako sakramentu miłości"18. Dodaje również, iż Wcielony Bóg przyciąga wszystkich ludzi do siebie. W tym kontekście chrześcijańska agape staje się określeniem Eucharystii. To właśnie w Eucharystii agape Boga przychodzi do Kościoła cieleśnie, aby nadal w nim i przez niego działać ${ }^{19}$.

Papież Benedykt, w nawiązaniu do nauczania Ojca Świętego Jana Pawła II widzi przyczynowy związek pomiędzy ofiarą Chrystusa, Eucharystią i Kościołem. Odwołując się do encykliki Ecclesia de Eucharistia

\footnotetext{
${ }^{14}$ Por. B. Nadolski, Liturgika. Liturgia i czas, t. 2, Poznań 1991, s. 8-9.

15 ASC, nr 36.

16 Por. EE, nr 21.

$17 \mathrm{KK}, \mathrm{nr} 3$.

18 ASC, nr 5.

19 Por. tamże.
} 
potwierdza, że Kościół „żyje dzięki Eucharystii”. W każdej Eucharystii zbawcza ofiara Chrystusa uobecnia się oraz się aktualizuje i właśnie dlatego istnieje ścisły przyczynowy związek między Eucharystią i początkiem Kościoła ${ }^{20}$. Te myśli św. Jana Pawła II pozwalają Benedyktowi XVI stwierdzić: „Eucharystia jest Chrystusem, który nam się daje, budując nas nieustannie jako swoje ciało. Dlatego w sugestywnym ruchu kołowym pomiędzy Eucharystią, która buduje Kościół, i samym Kościołem, który sprawuje Eucharystię, pierwotną przyczyną jest ta, która wyraża się w stwierdzeniu: Kościół może celebrować i adorować tajemnicę Chrystusa obecnego w Eucharystii właśnie dlatego, że sam Chrystus dał się w niej pierwszy poprzez ofiarę Krzyża. Możliwość „czynienia” Eucharystii przez Kościół jest całkowicie zakorzeniona w darze, jaki Chrystus złożył z samego siebie"21. W tym akcie objawia się bezinteresowna i całkowicie darmowa miłość Chrystusa do Kościoła. Jezus jest zawsze tym, który pierwszy nas umiłował (por. $1 \mathrm{~J}$ 4,19). Papież podkreśla, że wpływ przyczynowy Eucharystii na początek Kościoła objawia definitywnie pierwszeństwo chronologiczne i ontologiczne Jego miłości do Kościoła: „Przez całą wieczność, On jest tym, który pierwszy nas umiłował"22.

Można powiedzieć, że Benedykt XVI widzi Eucharystię jako nieustającą odrodzicielką Kościoła i właśnie dlatego w niej upatruje centrum życia chrześcijańskiego. Eucharystia staje swego rodzaju streszczeniem całej wiary Kościoła ${ }^{23}$. W niej zawiera się całe dobro duchowe Kościoła, czyli sam Chrystus, nasza Pascha i Chleb żywy, który przez swoje ożywione przez Ducha Świętego i ożywiające Ciało daje życie ludziom ${ }^{24}$. Eucharystia oznacza i cudownie urzeczywistnia komunię życia z Bogiem i jedności całego Ludu Bożego. Komunia ta jest nieustannie podtrzymywana mocą sakramentu ołtarza, w której kapłan staje się alter Christus, łączącym niebo z ziemią. Nowe Przymierze zawarte z Chrystusem sprawia, że Kościół ma pełen udział Jego życiu. W sposób szczególny prawda ta realizuje się

20 Por. EE, nr 1; 21.

${ }^{21}$ ASC, nr 14; por. J. Grześkowiak, Oto wielka tajemnica wiary, Poznań 1987, s. $158-184$.

22 Tamże.

${ }^{23}$ Por. tamże 6; por. A. Cuva, Vita nello Spirito e celebrazione eucharistica, Città del Vaticano 1994, s.143-145.

${ }^{24} \mathrm{DP}, \mathrm{nr} 5$. 
w Eucharystii. Ona jednocześnie tworzy Kościół i urzeczywistnia jego jedność Kościoła ${ }^{25}$.

Istnienie i działanie Kościoła jest ściśle związane z Eucharystią. Papież Benedykt XVI przypomniał, że w starożytności chrześcijańskiej tym samym pojęciem określano ciało Chrystusa zrodzone z Maryi Dziewicy, Ciało eucharystyczne i Ciało Kościoła. W stwierdzeniu tym wyraźnie widać nierozerwalną więź Chrystusa i Kościoła. Eucharystia jest źródłem komunii eklezjalnej. W epiklezie komunijnej II modlitwy eucharystycznej Kościół prosi Boga, ,aby Duch Święty zjednoczył nas wszystkich przyjmujących Ciało i Krew Chrystusa"26. Słowa te pozwalają zrozumieć w jaki sposób rzeczywistość sakramentalna Eucharystii stanowi źródło jedności wiernych w kościelnej komunii. Od chwili powstania Kościoła Eucharystia jawi się jako tajemnica komunii.

Wcześniej, św. Jan Paweł II w encyklice Ecclesia de Eucharistia zwrócił uwagę na relację między Eucharystią i communio. Podkreślał, że stanowi ona najwyższy sakramentalny wyraz komunii w Kościele ${ }^{27}$. Można zatem stwierdzić, że Eucharystia została utworzona nie tylko dla poszczególnego człowieka, ale dla całego Kościoła, który jest wspólnotą zgromadzoną przez Chrystusa przy stole Eucharystycznym. Wspólnota jedności i miłości w sposób szczególny objawia się w czasie sprawowania Eucharystii w Kościele partykularnym. Benedykt XVI podkreśla, że „rzeczywistość jednej Eucharystii, sprawowanej w każdej diecezji wokół własnego biskupa, pozwala zrozumieć, jak Kościoły partykularne trwają „in” i „ex” Ecclesia” ${ }^{28}$. Tutaj znajdujemy uzasadnienie dla stwierdzenia, że Eucharystii każdy wierny znajduje się w swoim, to znaczy w Chrystusowym Kościele.

Podsumowując, należy podkreślić, że według papieża Benedykta XVI Kościół jest budowany i podtrzymywany przy życiu dzięki Eucharystii. On urzeczywistnia się wówczas, gdy w braterskiej wspólnocie sprawuje i celebruje Chrystusową Ofiarę krzyża. Moc i piękno zawarte w sakramencie Eucharystii mają swój podmiot w Chrystusie ukrzyżowa-

\footnotetext{
${ }^{25}$ Por. KK, nr 3; 7; 11.

${ }^{26}$ Mszał rzymski dla diecezji polskich, Poznań 1986, s. 318* (dalej: MRP).

27 Zob. EE, nr 38.

${ }^{28}$ ASC, nr 15.
} 
nym, zmartwychwstałym i uwielbionym oraz w Duchu Świętym, który nieustannie uobecnia i aktualizuje zbawcze dzieło Pana, obecne w „sakramencie ołtarza”.

\section{EUCHARYSTIA JAKO ŹRÓDŁO UŚWIĘCENIA I ODNOWY ŚWIATA}

Eucharystia, budując Kościół Jezusa Chrystusa, ma również istotny wkład w uświęcenie i odnowienie świata. Ojciec Święty mocno zaznacza, że eucharystyczny kult w sposób skuteczny ogarnia wszystko: „Nowy chrześcijański wymiar kultu obejmuje każdy aspekt ludzkiej egzystencji, przemieniając ją"29. Chrześcijanin został powołany przez Chrystusa, aby wszystko czynić na chwałę Boga (por. 1 Kor 10, 31). Oznacza to, że w każdym akcie swojego życia winien wyrażać prawdziwy kult składany Bogu. Całe życie chrześcijanina od chwili chrztu, staje się swego rodzaju liturgią, czyli chwałą oddawaną Bogu. W tym kontekście szczególne miejsce zajmuje Eucharystia, gdyż życie chrześcijańskie z natury jest życiem eucharystycznym. W Eucharystii można odnaleźć wszystko to, co ludzkie, a więc myśli i uczucia, słowa i uczynki. Co więcej, to właśnie w niej mogą one być przeżywane najgłębiej i najpełniej. Dzięki temu „człowiek eucharystyczny”, angażując się w ludzką rzeczywistość, przemienia ją i czyni ją coraz bardziej podobną do Jezusa Chrystusa. Cała wartość antropologicznej radykalnej nowości przyniesionej przez Jezusa w Eucharystii wyrażą się w tym, że kult oddawany Bogu nie ogranicza się do prywatnej intymności, ale ze swej natury jego celem jest przeniknięcie każdego aspektu życia człowieka i świata. Tak przeżywana i rozumiana Eucharystia staje się tajemnicą, którą wierzący mogą i powinni ofiarować całemu światu ${ }^{30}$.

Według papieża Benedykta XVI Eucharystia jest tajemnicą do ofiarowania światu. Wynika to ze słów Jezusa, który w „Mowie eucharystycznej” Mówi: „Chlebem, który Ja wam dam, jest moje ciało [wydane] za życie świata” (J 6, 51). Jezus wypowiedział te słowa do wszystkich słuchających do Żydów i jeszcze przed ustanowieniem Eucharystii i oficjalnym

\footnotetext{
29 Tamże, nr 71.

30 Por. tamże.
} 
powstaniem Kościoła. Oznacza to, że Eucharystia ma wymiar uniwersalny i według woli Jezusa stanowi dar da całego świata. Należy pamiętać, że ofiara złożona przez Chrystusa i teraz uobecniana w Eucharystii ma również wymiar kosmiczny i dzięki niej dokonało się odkupienie całego wszechświata $^{31}$.

Jezus przyszedł na świat jako Zbawiciel wszystkich ludzi. On sam nikogo nie wykluczył ze swojego zbawczego dzieła. Ziemska misja Jezusa odsłania Jego miłość i współczucie do każdego człowieka, a szczególnie do grzeszników i osób chorych i cierpiących. Święty papież Jan Paweł II w Liście Apostolskim Salvifici doloris pisał: „W swej mesjańskiej działalności wśród Izraela, Chrystus przybliżał się nieustannie do świata ludzkiego cierpienia. Przeszedł dobrze czyniąc" (Dz 10, 38) - a czyny te odnosiły się przede wszystkim do cierpiących i oczekujących pomocy. Uzdrawiał chorych, pocieszał strapionych, karmił głodnych, wyzwalał ludzi od głuchoty, ślepoty, trądu, opętania i różnych kalectw, trzykrotnie przywrócił umarłego do życia. Był wrażliwy na każde ludzkie cierpienie, zarówno cierpienie ciała, jak duszy" ${ }^{2}$. Służba uzdrawiania stanowiła centralne miejsce w zbawczej misji Jezusa. Udzielając odpowiedzi uczniom Jana Chrzciciela, Jezus mówi: „Idźcie i donieście Janowi, to, coście widzieli i słyszeli: niewidomi wzrok odzyskują, chromi chodzą, trędowaci doznają oczyszczenia i głusi słyszą; umarli zmartwychwstają, ubogim głosi się Ewangelię" (Łk 7, 22).

Nowy Testament przedstawia Jezusa jako wielkiego lekarza, który leczył ludzi z wielu chorób. Ewangelie opisują 32 cuda dokonane przez Jezusa, z czego aż 25 dotyczy uzdrowienia chorych. Do Jezusa z każdego miejsca przybywali ludzie dotknięci różnymi chorobami. W spotkaniach z chorymi Jezus był zawsze wewnętrznie poruszony, okazywał im swoją miłość, zrozumienie i solidarność. Uzdrowienia dokonane przez Jezusa obejmują szeroką gamę chorób: gorączka (Mt 8, 14), trąd (Mt 8, 2-4), paraliż (Mt 9, 2-8), sucha ręka (Mt 12, 9-14), krwotok (Mt 9, 20-22), epilepsja (Mt 17, 14-21), ślepota (Mt 20, 29-34; J 9, 1-7), głuchota (Mt 12, 22-24), głuchoniemy (Mk 7, 31-37). Szczególne miejsce w dzia-

${ }^{31}$ Por. tamże, nr 88; por. J. Grześkowiak, Eucharystia człowiek świat, Włocławek 1997, s. 222-241.

32 Jan Paweł II, List apostolski Salvifici doloris, Wrocław 1984, nr 16. 
łalności terapeutycznej Jezusa zajmowały egzorcyzmy. Jezus uwolnił wielu ludzi opętanych przez złe duchy (Mt 8, 28-34; Mt 9, 32-34; Mk 1, 21-27). Zdarzyły się także przypadki wskrzeszenia umarłych (Łk 14, 1-4; J 11, 38-44) $)^{33}$.

Można powiedzieć, że te głębokie uczucia Jezusa względem grzeszników i cierpiących wyrażają zbawczy zamysł Boga wobec każdego człowieka. Pragnieniem Boga jest bowiem zbawienie wszystkich ludzi. W tym kontekście Ojciec Święty Benedykt XVI stwierdza, iż

Każda celebracja eucharystyczna aktualizuje sakramentalnie dar, jaki Jezus uczynił z własnego życia przez śmierć na Krzyżu, dla nas oraz dla całego świata. Równocześnie w Eucharystii Jezus czyni z nas świadków współczucia Boga wobec każdego brata i siostry. W ten sposób rodzi się wokół tajemnicy eucharystycznej służba miłości wobec bliźniego, która polega właśnie na tym, że kocham w Bogu i z Bogiem również innego człowieka, którego w danym momencie może nawet nie znam lub do którego nie czuję sympatii ${ }^{34}$.

Jakże w tym miejscu nie wrócić do Wieczernika i do bardzo wzruszającego i głębokiego w treści gestu umycia przez Jezusa uczniom nóg. On daje przykład postawy swoim uczniom względem siebie nawzajem i względem innych ludzi: powinniście sobie nawzajem umywać nogi (J 13, 14). Należy podkreślić, że ten gest został uczyniony w kontekście ustanowionej Eucharystii i przed całkowitym uniżeniem się Jezusa, które dokonało się na drzewie Krzyża. Jezus pokazał, co oznacza w praktyce miłować Boga i bliźniego, czyli realizować w codzienności najważniejsze przykazania (por. Mt 22, 34-40). Miłość do bliźniego może być urzeczywistniona tylko wtedy, gdy jej punktem wyjścia jest intymne spotkanie z Bogiem. Ono pozwala patrzeć na drugiego człowieka nie tylko własnymi oczami i przez pryzmat własnych odczuć, lecz także z perspektywy Chrystusa ${ }^{35}$.

${ }^{33}$ Por. R. Fabris, I miracoli di Gesú, i suoi riti di guarigione e la predicazione del regno di Dio, w: Liturgia e terapia. La sacramentalità a servizio dell'uomo nella sua interezza, red. A.N. Terrin, Padova 1994, s. 57-63.

${ }^{34}$ ASC, $\mathrm{nr} 88$.

35 Por. Benedykt XVI, Encyklika Deus caritas est, Kraków 2006, nr 18. 
Te rozważania z encykliki Deus caritas est prowadzą papieża Benedykta XVI do bardzo mocnego stwierdzenia: „nasze wspólnoty, gdy celebrują Eucharystię, powinny być bardziej świadome, że ofiara Chrystusa jest dla wszystkich ludzi i dlatego Eucharystia przynagla każdego weń wierzącego, by stawał się „chlebem łamanym” dla innych, a więc by angażował się na rzecz świata bardziej sprawiedliwego i braterskiego. Naprawdę, powołaniem każdego z nas jest, byśmy wraz z Jezusem byli „chlebem łamanym za życie świata"36. Również dziś, wobec niesprawiedliwości społecznych, podziałów, a przede wszystkim wobec katastrofy głodu, papież przywołuje słowa Chrystusa skierowane do swoich uczniów: „Wy dajcie im jeść” (Mt 14, 16).

Z Eucharystii wypływają bardzo konkretne konsekwencje społeczne. Jedność z Chrystusem tworzy nowe relacje międzyludzkie. Kolejny raz nawiązując do encykliki Deus caritas est, papież pisze, że „mistyka tego sakramentu ma charakter społeczny, bowiem zjednoczenie z Chrystusem jest jednocześnie zjednoczeniem $z$ wszystkimi, którym On się daje. Nie mogę mieć Chrystusa tylko dla siebie; mogę do Niego należeć tylko w jedności z wszystkimi, którzy już stali się lub staną się Jego" ${ }^{37}$. W Eucharystii, sakramencie miłości, wierzący doświadcza miłości Chrystusa wypływającej z Jego ofiary złożonej na Krzyżu. Ta miłość zawarta jest w każdej Mszy Świętej. Jedyną pozytywną odpowiedzią na dar tej miłości może być miłość okazywana bliźnim. Św. Jan Apostoł bardzo jasno mówi: „Jeśliby ktoś mówił: «Miłuję Boga», a brata swego nienawidził, jest kłamcą, albowiem kto nie miłuje brata swego, którego widzi, nie może miłować Boga, którego nie widzi” (1 J 4, 20). Uczestnictwo w Eucharystii w naturalny sposób domaga się miłości Boga i bliźniego ${ }^{38}$.

W dalszej części adhortacji Ojciec Święty Benedykt XVI podkreśla, że społeczny charakter Eucharystii wyraża się przede wszystkim w dążeniu do pojednania. Wprost stwierdza, iż

tylko ciągłe dążenie do pojednania pozwala na godne przyjmowanie Ciała i Krwi Pańskiej (por. Mt 23-24) ${ }^{39}$. Myśl ta była obecna w chrześcijaństwie od początku. Już w Didache czytamy: W Dzień zaś Pański gromadźcie

\footnotetext{
${ }^{36}$ ASC, nr 88.

37 Benedykt XVI, Encyklika Deus caritas est, nr14.

${ }^{38}$ Por. J. Grześkowiak, Eucharystia człowiek świat, s. 6176.

39 ASC, nr 89.
} 
się, łamcie chleb i dzięki czyńcie, wyznawszy wpierw grzechy swoje, iżby czystą była ofiara wasza. Ktokolwiek zaś waśni się z bratem swoim, niech nie uczestniczy w waszym zebraniu, dopóki się nie pojedna, aby nie splamił waszej ofiary. Mówi bowiem Pan: „W każdym miejscu i czasie składajcie Mi ofiarę czystą, jako że Król Wielki jestem, a imię Moje przedziwne między narodami” (Ml 1, 11.14) ${ }^{40}$.

Papież Benedykt XVI nie ma wątpliwości, że warunkiem budowania prawdziwego pokoju jest przywrócenie sprawiedliwości, pojednania i przebaczenia. Stąd przynagla wszystkie skonfliktowane strony do przyśpieszenia pojednania i otworzenia się na dialog budujący sprawiedliwośćc ${ }^{11}$.

Wola pojednania w naturalny sposób prowadzi do zmiany niesprawiedliwych struktur istniejących w świecie oraz do przywrócenia szacunku dla godności każdego człowieka stworzonego na obraz i podobieństwo Boże. Podjęcie takiej odpowiedzialności sprawi, że Eucharystia stanie się w codziennym życiu tym, co celebruje i uobecnia, czyli stanie się źródłem przebaczenia i pojednania. Stąd Kościół nie może być marginalizowany w walce o sprawiedliwość społeczną. Już w encyklice Deus caritas est papież Benedykt pisał: „Kościół musi włączyć się w nią przez argumentację rozumową i obudzić siły duchowe, bez których sprawiedliwość, domagająca się zawsze wyrzeczeń, nie może utrwalić się i rozwijać"42. Moc do zaangażowania się $\mathrm{w}$ przemianę świata chrześcijanin czerpie $\mathrm{z}$ Eucharystii, która uobecnia „ofiarę wyzwolenia”. Uczestnictwo w Eucharystii zobowiązuje wszystkich wierzących do zaangażowania się w proces budowania pokoju i sprawiedliwości społecznej. Do największych problemów świata, które winny być rozwiązane papież zalicza: przemoc, wojny, terroryzm, korupcję ekonomiczną oraz wyzysk seksualny. Te problemy trzeba rozwiązywać kompleksowo i skutecznie. Stanie się tak, gdy zostaną zdemaskowane okoliczności, które przeciwstawiają się godności człowieka, za którego umarł na Krzyżu Jezus Chrystus, potwierdzając niepowtarzalną wartość każdego pojedynczego człowieka ${ }^{43}$.

${ }^{40}$ Nauka Dwunastu Apostołów (Didache), rozdz. XIV, tekst polski w: Antologia literatury patrystycznej, oprac. M. Michalski, t. I, Warszawa 1975, s. 20.

${ }^{41}$ Por. ASC, nr 89.

${ }^{42}$ Benedykt XVI, Encyklika Deus caritas est, nr 28.

${ }^{43}$ Por. ASC, nr 89; por. A. Grajewski, Eucharystia buduje Kościót jako wspólnotę 
Eucharystia jest dla człowieka wierzącego „pokarmem prawdy”. Prawda Eucharystii nie pozwala zamykać oczu na ludzką nędzę. Obowiązkiem „człowieka Eucharystii” jest demaskowanie prawdy o ludziach trwoniących bogactwa ziemi i prowokujących nierówności społeczne. Sam Chrystus będący „Chlebem życia wiecznego” uwrażliwia na sytuację biedy, w której wciąż znajduje się większa część ludzkości. Ojciec Święty Benedykt XVI pisze: „Pokarm prawdy przynagla nas do demaskowania sytuacji, które są niegodne człowieka, w których umiera się z powodu braku pożywienia, niesprawiedliwości lub wyzysku, daje nam też nową siłę i odwagę, by pracować wytrwale nad budowaniem cywilizacji miłości”"44. Historia Kościoła pokazuje, że chrześcijanie od początku dzielili się swoimi dobrami (por. Dz 4, 32) i pomagali ubogim. Bardzo wymowne jest tutaj świadectwo św. Justyna, który mówiąc o darach przynoszonych na Eucharystię pisze:

Kogo stać na to, a ma dobrą wolę, ofiarowuje datki jakie chce i może na ręce przełożonego. Ten roztacza opiekę nad sierotami, wdowami, chorymi, lub też z innego powodu cierpiącymi niedostatek, a także nad więźniami oraz obcymi goszczącymi w gminie; jednym słowem spieszy z pomocą wszystkim potrzebującym ${ }^{45}$.

Eucharystia, uobecniając nieskończoną miłość Chrystusa do ludzkości, jednocześnie uzdalnia i przynagla chrześcijan do odważnego angażowania się $\mathrm{w}$ struktury tego świata. Ich zaangażowanie ma wnosić w te struktury nowość odniesień, mających swe niewyczerpalne źródło w darze Boga. Chrześcijan świecki, uformowany w szkole Eucharystii jest wezwany i powołany do bezpośredniego podejmowania odpowiedzialności politycznej i społecznej. W tym dziele ma mu pomóc znajomość katolickiej nauki społecznej, która formowana przez wieki, charakteryzuje się realizmem i równowagą ${ }^{46}$.

prawdy, w: Eucharystia dar Chrystusa dla Kościoła posłanego do świata, red. J. Nagórny, J. Gocko, Lublin 2006, s. 59-74.

${ }^{44}$ ASC, nr 90; por. J. Grześkowiak, Eucharystia człowiek świat, s. 124-131.

${ }^{45}$ Justyn Męczennik, Apologia 67, tekst polski w: Antologia literatury patrystycznej, s. 97.

${ }^{46}$ Por. ASC, nr 91; por. A. Derdziuk, Eucharystyczny wymiar życia społecznego, w: Eucharystia dar Chrystusa dla Kościoła posłanego do świata, s. 91-102. 
Ojciec Święty Benedykt XVI widzi również wpływ Eucharystii na ekologię i cały kosmos. W relacji Eucharystii do kosmosu odkrywa się jedność Bożego zamysłu i można uchwycić głęboki związek między stworzeniem i „nowym stworzeniem”, które wzięło swój początek w zmartwychwstaniu Chrystusa. Poza tym zgromadzenie liturgiczne, składając dziękczynienie przez Eucharystię, winno mieć głęboką świadomość, że czyni to w imieniu całego stworzenia i przez to je uświęca. Msza Święta, poprzez składane dary chleba i wina będące „owocem ziemi” i „pracy rąk ludzkich”, wzywa nas do uznania ziemi jako Bożego stworzenia, które wytwarza ludziom potrzebne pożywienie. W związku z tym nie można posługiwać się ziemią nieodpowiedzialnie, kierując się chciwością i pożądliwością osiągania zysków. Nie można degradować ziemi jako dzieła stworzenia i stąd wielka troska o tworzenie warunków ekologicznych, dających równowagę dla życia na ziemi ${ }^{47}$.

Jezus Chrystus, udzielając misji uświęcania świata powiedział Apostołom: „Idźcie więc i nauczajcie wszystkie narody, udzielając im chrztu w imię Ojca i Syna, i Ducha Świętego [...] A oto Ja jestem z wami przez wszystkie dni, aż do skończenia świata" (Mt 28, 19-20). W tym wezwaniu należy doszukiwać się podstaw do uświęcenia i przemieniania świata. Moc do wypełnienia tej misji wypływa z Eucharystii, która jest niewyczerpalnym źródłem miłości Boga do człowieka i do świata.

\section{EUCHARYSTIA POKARMEM DAJĄCYM ŻYCIE WIECZNE}

Uczestnictwo w sakramencie Eucharystii dla wierzących jest realizacją zbawczego planu, którego końcem jest życie wieczne, we wspólnocie świętych w niebie. Papież Benedykt XVI stwierdza ten fakt w sposób jednoznaczny: „życie wieczne rozpoczyna się w nas już teraz poprzez zmianę, jaką dar eucharystyczny w nas rodzi: ten, kto Mnie spożywa, będzie żył przeze Mnie" (J 6, 57) ${ }^{48}$. Te słowa ukazują dynamikę liturgii Eucharystii w perspektywie życia wiecznego. Eucharystia jest uprzywilejowaną chwilą chrześcijańskiego życia, która nadaje bieg całemu istnieniu człowieka i świata.

\footnotetext{
${ }^{47}$ Por. ASC, nr 92.

48 Tamże, nr 70.
} 
We Mszy Świętej należy widzieć sens ludzkiej egzystencji, na końcu której nastąpi spotkanie z Chrystusem Zmartwychwstałym, obecnym tu i teraz w każdej celebracji eucharystycznej. W Eucharystii Kościół przekazuje i aktualizuje tajemnicę Odkupienia, dając człowiekowi udział w Bożym zbawieniu. W czasie ziemskiego pielgrzymowania człowiek dostępuje rzeczywistości nadprzyrodzonej, spożywając Ciało i Krew Chrystusa. Eucharystia jest znakiem rzeczywistości nadprzyrodzonej i wskazuje na realną obecność Chrystusa, którego teraz człowiek spotyka i przyjmuje w wierze. Ta wiara wybiega ku przyszłości, czyli ku eschatologii i ma na względzie życie wieczne. Stąd w mszalnym Credo Kościół wyznaje: „I oczekuję wskrzeszenia umarłych i życia wiecznego w przyszłym świecie”"49. Tę pewność daje Eucharystia, którą papież Benedykt XVI nazywa: „darem danym człowiekowi, który jest w drodze" ${ }^{\text {" }}$.

W sakramencie chrztu człowiek otrzymał zalążek życia wiecznego. W czasie ziemskiego pielgrzymowania rozwija go i umacnia poprzez spożywanie Eucharystii. Ojciec Święty Benedykt XVI bardzo mocno podkreśla, że szczególnie w Eucharystii już dane nam jest uprzednie kosztowanie eschatologicznego spełnienia. W tym kierunku zmierza każdy człowiek i całe stworzenie. Dar życia wiecznego ściśle wiąże się z darem stworzenia. Człowiek został stworzony i powołany dla prawdziwej i wiecznej szczęśliwości. Te dary może dać tylko i wyłącznie Bóg. Wypływają one z bezinteresownej miłości Boga do człowieka i świata. Ostateczną metą ludzkiego życia jest Chrystus Uwielbiony, który już teraz staje się obecny dla nas w Eucharystii ${ }^{51}$.

Dziś wielu ludzi zatraciło wiarę w życie wieczne lub w nie powątpiewa, czując, obawę i lęk przed spotkaniem z Chrystusem Zmartwychwstałym na Sądzie Ostatecznym ${ }^{52}$. Tymczasem nie można zapominać, że Bóg powołuje nas do życia wiecznego. Papież Benedykt XVI zachęca wszystkich do niesłabnącej nadziei i wiary w życie wieczne, którego już można kosztować. Kościół celebrujący Eucharystię ma być dla świata znakiem i narzędziem eschatologicznego spotkania: „Chrystus darem

\footnotetext{
${ }^{49}$ MRP, s. $14^{*}$.

${ }^{50}$ ASC, nr 30.

51 Por tamże.

${ }^{52}$ Por. J. Ratzinger, Eucharystia - Bóg blisko nas, s. 149-151.
} 
z siebie samego rozpoczął czas eschatologiczny. Pragnie, aby Kościół przez Niego założony, stał się w historii znakiem i narzędziem eschatologicznego spotkania" ${ }^{3}$.

W tajemnicy sakramentu ołtarza wymiar eschatologiczny przypominają słowa aklamacji wypowiadane po przeistoczeniu: oczekujemy Twego przyjścia w chwale ${ }^{54}$. Kościół w ten sposób wskazuje na eschatologię sakramentu Eucharystii. W tym kontekście Benedykt XVI odwołuje się do biblijnego obrazu uczty eschatologicznej. Jezus, przychodząc na ziemię, wszedł $\mathrm{w}$ relacje z oczekiwaniami Izraela, całej ludzkości oraz całego stworzenia. On stał się człowiekiem, aby zgromadzić rozproszony Lud Boży w jedną wspólnotę Nowego Przymierza. Ustanawiając Eucharystię i nakazując Apostołom, by sprawowali Jego pamiątkę, pokazuje, że Jego pragnieniem jest, by Kościół był znakiem i narzędziem otwierającym przed ludzkością bramy życia wiecznego. Stąd papież podkreśla, iż „W każdej celebracji eucharystycznej realizuje się sakramentalnie eschatologiczne gromadzenie się Ludu Bożego. Uczta eucharystyczna jest dla nas rzeczywistą antycypacją ostatecznej uczy, zapowiedzianej uprzednio przez proroków (por. Iz 25, 6-9) i opisanej w Nowym Testamencie jako „gody Baranka” (Ap 19, 7-9), którą się celebruje w radości świętych obcowania"55. Należy pamiętać, że Eucharystia została ustanowiona podczas uczty i jako uczta. Istotą uczty jest spożywanie posiłku. W Eucharystii tym posiłkiem jest sam Jezus Chrystus, obecny pod postaciami chleba i wina. Wcześniej On sam zapewniał, że kto żywa Jego Ciało i pije Jego Krew będzie miał życie wieczne (por. J 6, 54-56). Spożywanie pokarmu eucharystycznego jednoczy z Chrystusem, co jest jednoznaczne z wiecznością. W tym kontekście warto przypomnieć nauczanie św. Jana Pawła II: „Eucharystia - to Zmartwychwstanie, to Chrystus Zmartwychwstały, który stał się pokarmem! To pożywienie człowieka, którego Jezus przebóstwia, to wiatyk dla ludzi przeznaczonych do nowej formy istnienia, pokarm tego Życia, które przekracza granicę śmierci" ${ }^{36}$.

${ }^{53}$ Por. ASC, nr 31.

${ }^{54}$ MRP, s. 317.

55 ASC, nr 31; por. A. Cuva, Vita nello Spirito e celebrazione eucharistica, S. $145-150$.

${ }^{56}$ EE 19; por. J. Aldazábal, L'Ecucaristia, s. 260-265. 
Eschatologiczny wymiar Eucharystii często akcentują teksty modlitw mszalnych. W kolekcie soboty drugiego tygodnia Wielkiego Postu Kościół prosi Boga: „Ty przez swoje sakramenty dajesz nam udział w dobrach wiecznych, chociaż żyjemy jeszcze na ziemi; kieruj naszym życiem doczesnym i doprowadź nas do światłości, w której sam przebywasz" ${ }^{37}$. Podobną myśl znajdujemy w kolekcie z poniedziałku czwartego tygodnia Wielkiego Postu: „Wszechmogący Boże, Ty odnawiasz świat przez święte sakramenty, spraw, aby Twój Kościół czerpał z nich życie wieczne"58. W sposób całkowity eschatologią eucharystyczną przepełnione są wszystkie formularze mszy pogrzebowych ${ }^{59}$.

Eucharystia, będąca anamnezą śmierci, zmartwychwstania i oczekiwania na powrót Chrystusa w chwale, staje się w naturalny sposób zadatkiem przyszłej chwały. W tej chwale będzie uczestniczył cały człowiek, gdyż obietnicą zmartwychwstania i uwielbienia objęto zostało również ludzkie ciało. Celebrując Mszę Świętą, która uobecnia dzieło zbawienia, zostaje umocniona nadzieja zmartwychwstania ciał oraz możliwość ponownego spotkania ze zmarłymi, którzy odeszli z tego świata ze znakiem wiary. W tym kontekście papież Benedykt przypomina wiernym znaczenie modlitwy za zmarłych i zachęca do jej praktykowania, a szczególnie do odprawiania za nich Mszy Świętej ${ }^{60}$.

Sobór Watykański II nazwał Eucharystię szczytem i źródłem życia Kościoła $^{61}$. Oznacza to, że Kościół pielgrzymujący do niebieskiej ojczyzny powinien karmić się Eucharystią nieustannie. Jest to konieczne, ponieważ zjednoczenie z Chrystusem eucharystycznym daje dostęp do życia wiecznego. Stąd ziemskie życie człowieka winno stawać się okazją do nieustannego zanurzania się $\mathrm{w}$ łasce Boga, na końcu którego otrzyma on wieczną nagrodę życia wiecznego. Dlatego papież Benedykt wzywa: „Aby Eucharystia, pamiątka Paschy Pana, stawała się każdego dnia źródłem i szczytem misji Kościoła"62.

\footnotetext{
57 MRP, s. 81.

58 Tamże, s. 92.

59 Por. tamże, s. 204-242.

${ }^{60}$ Por. ASC, nr 32.

${ }^{61}$ Por. KK, nr 11.

${ }^{62}$ ASC, nr 93.
} 


\section{ZAKOŃCZENIE}

Adhortacja apostolska Sacramentum Caritatis, Ojca Świętego Benedykta XVI, wpisuje się w sposób bardzo głęboki w nurt posoborowego nauczania Kościoła o Eucharystii. Należy zauważyć i podkreślić częste odwoływanie się do myśli swojego poprzednika św. Jana Pawła II i jego encykliki Ecclesia de Eucharistia. Można odnieść wrażenie, że adhortacja stanowi kontynuację i pogłębienie encykliki i jest pisana jakby przez tego samego autora. Oba dokumenty podkreślają wielkość i bezinteresowność miłości Chrystusa do człowieka i świata obecnej w Eucharystii. Źródłem tej miłości jest obecność Chrystusa i Jego zbawczego misterium paschalnego. Eucharystia przedstawiona jest jako dar i szansa dla człowieka i świata. Dar bezinteresownej miłości Chrystusa obecnego i działającego w każdej Eucharystii staje się szansą dla przemiany człowieka i świata. Eucharystia jest szansą dla tworzenia cywilizacji miłości. Ona już teraz otwiera przed człowiekiem "nową ziemię" i „nowe niebo”. Pozwala także już tu i teraz partycypować w wiecznej szczęśliwości, dla której został stworzony człowiek i świat.

Mając świadomość wielkiego eucharystycznego obdarowania, w kontekście utraty głodu Eucharystii przez wielu wiernych, trzeba dziś poprzez pogłębioną mistagogię odsłaniać wiernym wielkość Bożego daru, którym jest Eucharystia. Duszpasterze, katecheci poprzez studium powinni pogłębiać swoją wiedzę o Eucharystii, aby potem przekazywać ją wiernym. Ich przekaz będzie autentyczny i prawdziwy, gdy wiedzy będzie towarzyszyła żywa wiara w eucharystyczną obecność Chrystusa. W przypadku kapłanów ten przekaz będzie również czytelny w ars celebrandi Eucharystii i wierności przepisom liturgicznym. Nie można osłabiać i zaciemniać tak wielkiego daru nadużyciami i „bylejakością” celebracji.

Mając na uwadze osobiste kryzysy przeżywane przez współczesnego człowieka, kryzysy rodzinne i małżeńskie oraz problemy społeczne objawiające się w niesprawiedliwości, biedzie, wyzysku, konfliktach zbrojnych, trzeba dostrzec w Eucharystii sakrament uzdrowienia i pojednania. Uczestnictwo w Eucharystii może stać się najlepszą szkołą miłości, braterstwa, pokoju i pojednania. W niej człowiek może odnaleźć prawdziwe szczęście, którego tak często bezskutecznie szuka w świecie. W Eucharystii też otrzymuje pełnię prawdziwego życia, czyli życie wieczne. Dzięki niej 
życie wieczne nie jest fikcyjnym marzeniem, ale prawdą realizującą się już w życiu ziemskim.

\section{BIBLIOGRAFIA}

Aldazábal J., L'Ecucaristia, w: La celebrazione nella Chiesa. I sacramenti, red. D. Borobio, t. 2, Torino1994, s. 195-484.

Benedykt XVI, Encyklika Deus caritas est, Kraków 2006.

Benedykt XVI, Posynodalna Adhortacja Apostolska Sacramentum Caritatis, Poznań 2007. Cuva A., Vita nello Spirito e celebrazione eucharistica, Città del Vaticano 1994.

Fabris R., I miracoli di Gesú, i suoi riti di guarigione e la predicazione del regno di Dio, w: Liturgia e terapia. La sacramentalità a servizio dell'uomo nella sua interezza, red. A.N. Terrin, Padova 1994, s. 54-85.

Grajewski A., Eucharystia buduje Kościół jako wspólnotę prawdy, w: Eucharystia dar Chrystusa dla Kościoła posłanego do świata, red. J. Nagórny, J. Gocko, Lublin 2006, s. 59-74.

Grześkowiak J., Eucharystia człowiek świat, Włocławek 1997.

Grześkowiak J., Oto wielka tajemnica wiary, Poznań 1987.

Jan Paweł II, Encyklika o Eucharystii w życiu Kościoła Ecclesia de Eucharistia, Poznań 2003.

Jan Paweł II, List apostolski Salvifici doloris, Wrocław 1984.

Justyn Męczennik, Apologia 65-67, w: Antologia literatury patrystycznej, oprac. M. Michalski, t. I, Warszawa 1975, s. 96-97.

Mszał rzymski dla diecezji polskich, Poznań 1986.

Nadolski B., Liturgika. Liturgia i czas, t. 2, Poznań 1991.

Nadolski B., Wprowadzenie do liturgii, Kraków 2004.

Nagórny J., Eucharystia - we wspólnocie i dla wspólnoty, w: Eucharystia - miłość i dziękczynienie, red. W. Słomka, A.J. Nowak, Lublin 1992, s. 123-140.

Nauka Dwunastu Apostołów, Didache, w: Antologia literatury patrystycznej, oprac. M. Michalski, t. I, Warszawa 1975, s. 18-20.

Ratzinger J., Eucharystia - Bóg blisko nas, Kraków 2005.

Sobór Watykański II, Dekret o posłudze i życiu prezbiterów Presbyterorum ordinis, w: Sobór Watykański II, Konstytucje. Dekrety. Deklaracje, Poznań 2002, s. 478-508.

Sobór Watykański II, Konstytucja dogmatyczna o Kościele Lumen Gentium, w: Sobór Watykański II, Konstytucje. Dekrety. Deklaracje, Poznań 2002, s. 104-208.

Sobór Watykański II, Konstytucja o Liturgii Świętej Sacrosanctum Concilium, w: Sobór Watykański II, Konstytucje. Dekrety. Deklaracje, Poznań 2002, s. 49-78. 